\title{
Application of a Stability-Indicating HPTLC Method for Simultaneous Quantitative Determination of Olmesartan Medoxomil and Hydrochlorothiazide in Pharmaceutical Dosage Forms
}

\author{
Kaliappan Ilango ${ }^{1}$ and Pushpangadhan S. Shiji Kumar ${ }^{2}$ \\ ${ }^{1}$ Department of Pharmaceutical Chemistry, SRM College of Pharmacy, SRM University, Kattankulathur, Kancheepuram, \\ Tamil Nadu 603 203, India \\ ${ }^{2}$ Department of Pharmaceutical Chemistry, Jamia Salafiya Pharmacy College, Pulikkal, Malappuram, Kerala 673 637, India
}

Correspondence should be addressed to Pushpangadhan S. Shiji Kumar; shijikps@gmail.com

Received 29 May 2013; Revised 20 September 2013; Accepted 20 September 2013

Academic Editor: Sibel A. Ozkan

Copyright (C) 2013 K. Ilango and P. S. Shiji Kumar. This is an open access article distributed under the Creative Commons Attribution License, which permits unrestricted use, distribution, and reproduction in any medium, provided the original work is properly cited.

\begin{abstract}
A rapid, precise, sensitive, economical, and validated high performance thin layer chromatographic method is developed for simultaneous quantification of olmesartan medoxomil and hydrochlorothiazide in combined tablet dosage form. The method used amlodipine as internal standard (IS). Chromatographic separations were achieved on silica gel $60 \mathrm{~F}_{254}$ plates using toluenemethanol-ethyl acetate-acetone $(2.5: 1: 0.5: 2, \mathrm{v} / \mathrm{v} / \mathrm{v} / \mathrm{v})$ as mobile phase. Densitometric analysis was carried out in the reflectance mode at $258 \mathrm{~nm}$. Calibration curves were linear over a range of $80-480 \mathrm{ng} / \mathrm{b}$ and for olmesartan medoxomil and $25-150 \mathrm{ng} / \mathrm{band}$ for hydrochlorothiazide. The detection and quantification limits were found to be 18.12 and $56.35 \mathrm{ng} / \mathrm{band}$ for olmesartan medoxomil and 6.31 and $18.56 \mathrm{ng} / \mathrm{band}$ for hydrochlorothiazide, respectively. Intra- and interassay precision provided relative standard deviations lower than $2 \%$ for both analytes. Recovery from 99.60 to $101.22 \%$ for olmesartan medoxomil and 98.30 to $99.32 \%$ for hydrochlorothiazide show good accuracy. Both the drugs were also subjected to acid, alkali, oxidation, heat, and photodegradation studies. The degradation products obtained were well resolved from pure drugs with significantly different $R_{f}$ values. As the method could effectively separate the drugs from their degradation products, it can be used for stability-indicating analysis. Validation of the method was carried out as per international conference on harmonization (ICH) guidelines.
\end{abstract}

\section{Introduction}

Olmesartan medoxomil (OLM), chemically 2,3-dihydroxy2-butenyl 4-(1-hydroxy-1-methylethyl)-2-propyl-1-[p- $(O-1 \mathrm{H}$ tetrazol-5-yl phenyl) benzyl] imidazole-5-carboxylate, cyclic 2,3-carbonate is a prodrug and it is hydrolysed to olmesartan during absorption from the gastrointestinal tract (Figure 1(a)). It is a selective AT1 subtype angiotensin II receptor antagonist. Hydrochlorothiazide (HTZ), chemically 6-chloro-3,4-dihydro-2,4-1,2,4-benzothiadiazine-7-sulfonamide-1,1-dioxide (Figure 1(b)), is a widely used thiazide diuretic [1-3]. Olmesartan and hydrochlorothiazide are available in the market as a combined dosage form for treatment of hypertension. Extensive literature survey revealed determination of OLM in dosage form by UV-visible spectrophotometry [4, 5], HPLC-UV [6, 7], and capillary electrophoresis [8]; in biological fluids by HPLC [9] and LC-MS [10, 11]. Determination methods of HTZ in pharmaceutical dosage form and biological fluids include chemiluminescence [12], HPLC [13], and electrochemical study [14]. Determination methods of OLM and HTZ combination include UV-spectrophotometry [15-18], RP-HPLC, and HPTLC [19, 20].

Till now, no stability indicating HPTLC method using an internal standard has been reported for simultaneous determination of OLM and HTZ for the combined dosage form. The objective of the present work is to develop and 


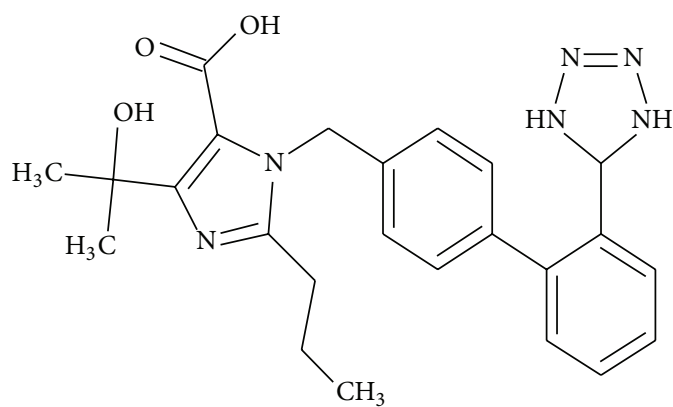

(a)<smiles>NS(=O)(=O)c1cc2c(cc1Cl)NCNS2(=O)=O</smiles>

(b)

FIGURE 1: Chemical structure of (a) olmesartan medoxomil (b) hydrochlorothiazide.

validate simple, sensitive, economic, rapid, precise, and accurate stability indicating HPTLC method for simultaneous determination of OLM and HTZ in accordance with ICH guidelines. HPTLC enables rapid analysis at lower cost than other techniques with selectivity, accuracy, and reproducibility. HPTLC also facilitates repeated detection (scanning) of chromatogram with the same or different parameters. In HPTLC, the consumption of mobile phase is quite low. Therefore the proposed method is very useful for routine analysis in quality control and can be used for assessing the stability of OLM and HTZ in pharmaceutical preparations.

\section{Experimental}

2.1. Chemicals, Reagents, and Solutions. Pharmaceutical grade olmesartan medoxomil ( $\geq 98.0 \%)$, hydrochlorothiazide $(\geq 99.0 \%)$, and internal standard amlodipine IS $(\geq 99.0 \%)$ were supplied by A To Z Laboratories, Chennai, India. Tablets, Olmesar-H (Macleods Pharmaceuticals Pvt. Ltd) and Olmy-H (Zydus Cadila Healthcare Ltd) both labeled to contain $40 \mathrm{mg}$ OLM and $12.5 \mathrm{mg}$ HTZ, were purchased from local pharmacy. Analytical grade methanol, toluene, ethyl acetate, and acetone (97 to $98 \% \mathrm{v} / \mathrm{v}$ ) were all obtained from M/s. Merck Chemicals, Mumbai, India. Stock solutions $(1.0 \mathrm{mg} / \mathrm{mL})$ of compounds were prepared by dissolving $25 \mathrm{mg}$ of OLM, IS, and HTZ standards individually into a $25 \mathrm{~mL}$ volumetric flask using methanol. A series of solutions containing mixture of drugs was prepared by transferring appropriate aliquots from standard stock solutions and diluting to volume with methanol. The final solution contained 8$48 \mu \mathrm{g} / \mathrm{mL}$ OLM, $2.5-15 \mu \mathrm{g} / \mathrm{mL}$ HTZ, and 5-30 $\mu \mathrm{g} / \mathrm{mL}$ IS. The concentration was fixed, taking into account the proportion in which OLM and HTZ are present in tablet formulation (3.2: 1 ratio).

2.2. Chromatography. Chromatographic separation of drugs was performed on Merck TLC plates precoated with silica gel $60 \mathrm{~F}_{254}(10.0 \times 10.0 \mathrm{~cm}$ with $250 \mathrm{~mm}$ layer thickness $)$ from E. Merck, Germany. Time for chamber saturation was optimized to 10 minutes. Sample and standard zones were applied to the plates as bands (number of tracks 7 , track distance from the left plate edges $20 \mathrm{~mm}$, distance from plate bottom $10 \mathrm{~mm}$, band length $1 \mathrm{~mm}$, and distance between bands $10 \mathrm{~mm}$ ) by means of Camag $100 \mu \mathrm{L}$ sample syringe (Hamilton, Switzerland) with a Linomat 5 applicator (Camag, Switzerland). The flow rate was $10 \mu \mathrm{Ls}^{-1}$ by using a nitrogen aspirator. The plates were left to equilibrate for 3 minutes in a $10.0 \times 10.0 \mathrm{~cm}$ horizontal chamber (Camag, Switzerland) and then developed to a distance of $80 \mathrm{~mm}$ using toluene : methanol : ethyl acetate : acetone $(2.5: 1: 0.5: 2, \mathrm{v} / \mathrm{v} / \mathrm{v} / \mathrm{v})$ as mobile phase. Separation was obtained within 10 minutes, and before detection, the plates were dried at $60^{\circ} \mathrm{C}$ for 4 minutes to eliminate mobile phase. Densitometric scanning was performed in the absorbance/reflectance mode at $258 \mathrm{~nm}$, using Camag TLC scanner 3 with deuterium source, slit dimension settings of length $2 \mathrm{~mm}$, width $0.1 \mathrm{~mm}$, monochromator band width $30 \mathrm{~nm}$, and scan rate of $4 \mathrm{mms}^{-1}$. WinCATS software (V1.4.2, Camag, Switzerland) was used for scanner control and data processing. Electronic balance (Shimadzu model AY120, Japan) was used for weighing purposes. The optimum absorption wavelength $(258 \mathrm{~nm})$ was determined by measuring in situ UV absorption spectrum of standard OLM and HTZ. The whole procedure took no more than 20 minutes. The $R_{f}$ values of OLM, HTZ, and IS were found to be $0.29 \pm$ $0.02,0.52 \pm 0.01$, and $0.71 \pm 0.01$, respectively. Concentrations of the compounds chromatographed were determined from the diffusely reflected light.

2.3. Method Validation. The proposed HPTLC method was validated for selectivity, precision, accuracy, linearity, robustness, LOD, LOQ, and recovery according to $\mathrm{ICH}$ guidelines $[21,22]$.

2.4. Selectivity. The selectivity of the method was assessed by analyzing in triplicate the standard and sample. The bands of OLM and HTZ from pharmaceutical formulation were confirmed by comparing $R_{f}$ values with those from standard. The peak purity was determined by win CATS software. The purity of each compound was confirmed by analyzing UV spectrum at start, apex, and end of peak.

2.5. Linearity and Sensitivity. For preparation of calibration plot, $10 \mu \mathrm{L}$ each of mixed standard solutions containing $8-48 \mu \mathrm{g} / \mathrm{mL}$ OLM, 2.5-15.0 $\mu \mathrm{g} / \mathrm{mL} \mathrm{HTZ}$, and $5-30 \mu \mathrm{g} / \mathrm{mL}$ IS were applied to the plate to furnish concentrations 


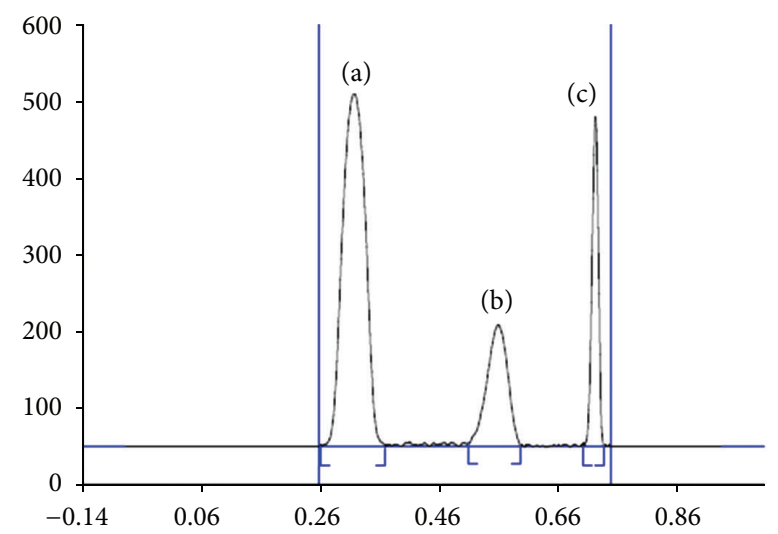

FIGURE 2: Representative chromatogram of OLM $\left(R_{f} 0.29\right)$, HTZ $\left(R_{f} 0.52\right)$, and IS $\left(R_{f} 0.71\right)$.

of 80-480 ng/band OLM, 25-150 ng/band HTZ, and 50$300 \mathrm{ng} / \mathrm{band}$ IS, respectively. Each standard was analysed in triplicate and peak areas were recorded. Calibration plots were constructed separately by plotting mean RRF (relative retention factor, peak area ratio of OLM or HTZ to IS) against respective concentrations of OLM and HTZ. The data were best fitted by linear equation $m x+b=y$. The sensitivity of the method was determined with respect to LOD, LOQ, linearity range, and correlation coefficient. The LOD and LOQ parameters were determined from the regression equations of OLM and HTZ. LOD $=3.3 \times \mathrm{SD} / s$ and $\mathrm{LOQ}=10 \times \mathrm{SD} / \mathrm{s}$, where SD is the standard deviation of the response and " $s$ " is the slope of corresponding calibration curve.

2.6. Precision. Precision is the measure of how the data values are close to each other for a number of measurements under the same analytical conditions and is expressed as relative standard deviation (\%RSD). The precision study was carried at three different concentrations (low, medium, and high) of OLM (80,320, and $480 \mathrm{ng} / \mathrm{band})$ and $\operatorname{HTZ}(25,100$, and $150 \mathrm{ng} / \mathrm{band}$ ) respectively.

2.7. Accuracy. Accuracy is the measure of how the experimental value is close to the true value and is expressed as $\%$ RSD, standard error mean (SEM), and \% recovery. Recovery studies by standard addition method were performed in a view to justify the accuracy of the proposed method. Previously analyzed samples containing OLM $(80,160$, and $240 \mathrm{ng} / \mathrm{band})$ and HTZ (25, 50, and $75 \mathrm{ng} / \mathrm{band})$ were spiked with standard $\operatorname{OLM}(25,50$, and $75 \mathrm{ng})$ and standard HTZ (25, 50 , and $75 \mathrm{ng}$ ). The mixtures were analyzed in triplicate by the proposed method.

2.8. Robustness. The robustness of an analytical procedure refers to its ability to remain unaffected by small and deliberate variations in method parameters and provides an indication of its reliability for routine analysis. To determine the robustness of method, the experimental conditions were deliberately altered and retention factor $\left(R_{f}\right)$, assay percent, and $\%$ RSD were evaluated. Conditions altered were mobile

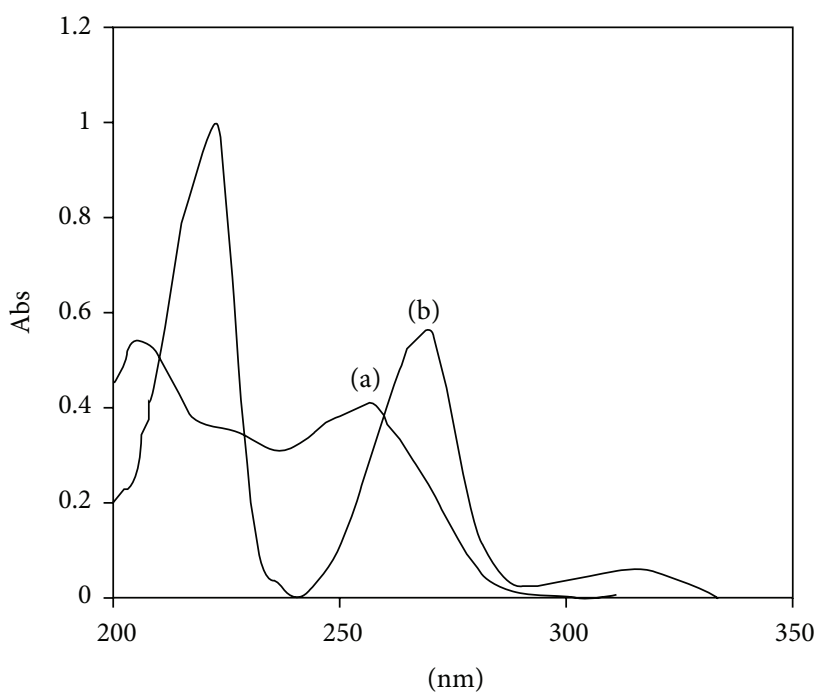

FIGURE 3: Typical overlaid absorption spectra of (a) OLM and (b) HTZ.

phase composition, development distance, time of spotting to chromatography, and detection wavelength. For all changes in conditions, the sample was analyzed in triplicate. When the effect altering one set of conditions was tested, the other conditions were held constant at optimum values.

2.9. Solution Stability. The stability of the drugs in solution during analysis was determined by repeated analysis of samples during the course of experimentation on the same day and also after storage of drug solution for five days under laboratory conditions $\left(25 \pm 2^{\circ} \mathrm{C}\right)$ and under refrigeration $(2-$ $\left.8^{\circ} \mathrm{C}\right)$. The samples were analyzed immediately and after a period of one, three, and five days.

2.10. Forced Degradation Studies. Forced degradation studies are performed to unequivocally identify the analyte of interest among other compounds expected to be present.

2.10.1. Acid-Induced Degradation Study. In this study, hydrochloric acid $(0.1 \mathrm{M}, 5 \mathrm{~mL})$ was added to $25 \mathrm{~mL}$ volumetric flask containing $0.8 \mathrm{~mL}, 0.25 \mathrm{~mL}$, and $0.5 \mathrm{~mL}$ of methanolic stock solutions of OLM, HTZ, and IS, respectively. The mixtures were refluxed at $50^{\circ} \mathrm{C}$ for 1 hour and completed to volume with methanol. $10 \mu \mathrm{L}$ of resulting solution was spotted as bands to furnish concentration of $320 \mathrm{ng} / \mathrm{band}$ OLM, $100 \mathrm{ng} / \mathrm{b}$ and HTZ, and $200 \mathrm{ng} / \mathrm{band}$ IS, respectively. The procedure was performed in dark excluding possible degradation from the effect of light.

2.10.2. Base-Induced Degradation Study. Sodium hydroxide $(0.1 \mathrm{M}, 5 \mathrm{~mL})$ was added to $25 \mathrm{~mL}$ volumetric flask containing $0.8 \mathrm{~mL}, 0.25 \mathrm{~mL}$, and $0.5 \mathrm{~mL}$ of methanolic stock solutions of OLM, HTZ, and IS, respectively. The mixtures were refluxed at $50^{\circ} \mathrm{C}$ for 1 hour and completed to volume with methanol. $10 \mu \mathrm{L}$ of resulting solution was spotted as bands to furnish concentration of $320 \mathrm{ng} / \mathrm{b}$ and OLM, $100 \mathrm{ng} / \mathrm{band}$ HTZ, and 


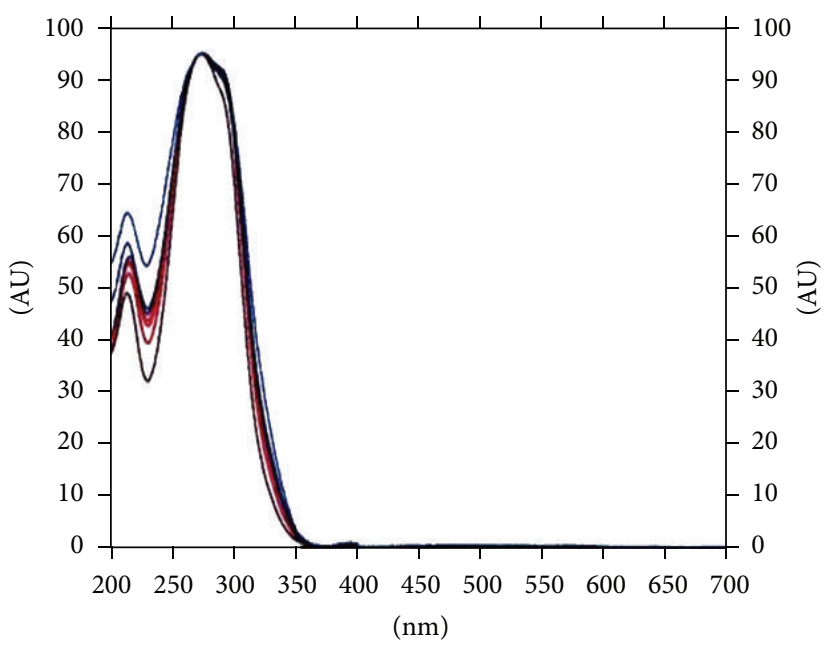

(a)

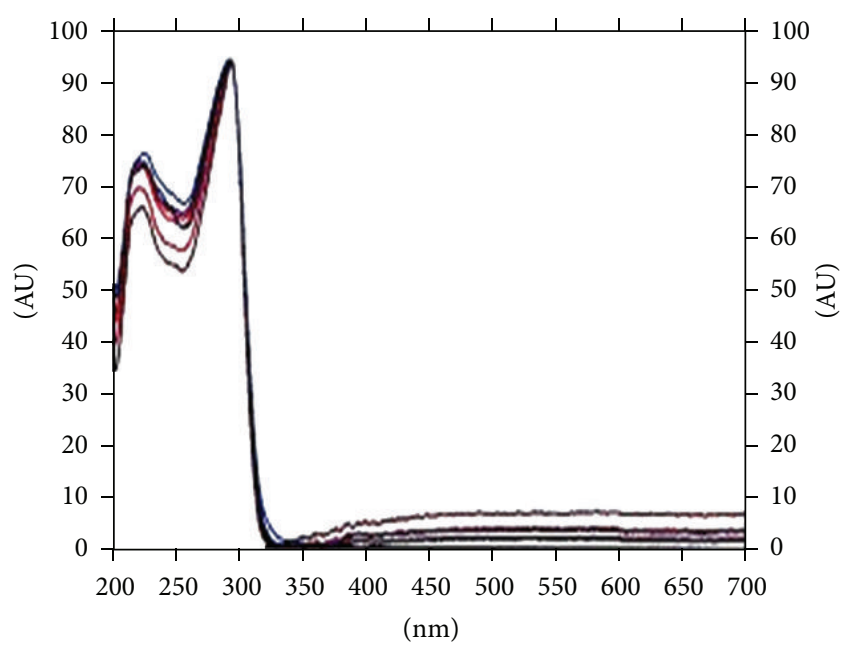

(b)

FIgURE 4: Peak purity spectra of (a) OLM and (b) HTZ. The wavelength selected for analysis was $258 \mathrm{~nm}$.

TABLE 1: Linearity parameters for calibration curve.

\begin{tabular}{|c|c|c|}
\hline Parameter & Olmesartan medoxomil & Hydrochlorothiazide \\
\hline Retention factor $\left(R_{f}\right)$ & 0.29 & 0.52 \\
\hline Linearity range (ng/band) & $80-480$ & $25-150$ \\
\hline Regression equation $(y=m x+b)$ & $y=1.32 x+0.95$ & $y=3.54 x+1.02$ \\
\hline Correlation coefficient $(r)$ & 0.9996 & 0.9999 \\
\hline Limit of detection (ng/band) & 18.12 & 6.31 \\
\hline Limit of quantification (ng/band) & 56.35 & 18.56 \\
\hline Standard deviation of slope ${ }^{\mathrm{a}}\left(S_{a}\right)$ & 0.9813 & 0.9012 \\
\hline Standard deviation of intercept ${ }^{\mathrm{a}}\left(S_{b}\right)$ & 1.2013 & 1.1430 \\
\hline Regression coefficient $\left(r^{2}\right)$ & 0.999 & 0.998 \\
\hline Peak purity index $(P)$ & 0.9986 & 0.9995 \\
\hline Method precision $^{\mathrm{a}}$ (RSD \%) & 0.92 & 0.84 \\
\hline
\end{tabular}

Mean of five replicates, RSD: relative standard deviation.

$200 \mathrm{ng} / \mathrm{b}$ and IS, respectively. The procedure was performed in dark excluding possible degradation from the effect of light.

2.10.3. Hydrogen Peroxide-Induced Degradation Study (Oxidation). Hydrogen peroxide $(3.0 \%, 5 \mathrm{~mL})$ was added to $25 \mathrm{~mL}$ volumetric flask containing $0.8 \mathrm{~mL}, 0.25 \mathrm{~mL}$, and $0.5 \mathrm{~mL}$ of methanolic stock solutions of OLM, HTZ, and IS, respectively. The mixtures were refluxed at $50^{\circ} \mathrm{C}$ for 1 hour and completed to volume with methanol. $10 \mu \mathrm{L}$ of resulting solution was spotted as bands to furnish concentration of $320 \mathrm{ng} / \mathrm{b}$ and OLM, $100 \mathrm{ng} / \mathrm{b}$ and HTZ, and $200 \mathrm{ng} / \mathrm{b}$ and IS, respectively. The procedure was performed in dark excluding possible degradation from the effect of light.

2.10.4. Wet Degradation Study. For wet degradation study, $0.8 \mathrm{~mL}, 0.25 \mathrm{~mL}$, and $0.5 \mathrm{~mL}$ of methanolic stock solutions of OLM, HTZ, and IS were transferred to $25 \mathrm{~mL}$ volumetric flask. To this, $5.0 \mathrm{~mL}$ methanol was added and the sample was refluxed at $60^{\circ} \mathrm{C}$ for 1 hour. The volume was made up with methanol and $10 \mu \mathrm{L}$ was applied to plate and analyzed under optimized chromatographic conditions.

2.10.5. Photodegradation Study. For photodegradation study, solution containing $320 \mathrm{ng} / \mathrm{b}$ and OLM, $100 \mathrm{ng} / \mathrm{band} \mathrm{HTZ}$, and $200 \mathrm{ng} / \mathrm{band}$ IS was exposed to UV light $(365 \mathrm{~nm})$ in a photostability chamber for 24 hours. The resulting solution was analyzed under optimized chromatographic conditions.

2.11. Analysis of Marketed Tablet Dosage Form. The application of the developed method was evaluated to determine the amounts of OLM and HTZ in their marketed tablet dosage form. Twenty tablets, each of both brands (Olmesar-H and Olmy-H), were accurately weighed. Their average weight was determined and pulverized to fine powder. A quantity of tablet powder equivalent to $40 \mathrm{mg}$ OLM and $12.5 \mathrm{mg} \mathrm{HTZ}$ was accurately weighed and transferred to $100 \mathrm{~mL}$ volumetric flasks. The volume was adjusted with methanol and the resultant solution was sonicated for 15 minutes and filtered 
TABLE 2: Results of precision studies of proposed method.

\begin{tabular}{|c|c|c|c|c|}
\hline \multirow{2}{*}{ Drug concentration (ng/band) } & \multicolumn{2}{|l|}{ Intraday precision } & \multicolumn{2}{|l|}{ Interday precision } \\
\hline & Calculated amount $^{\mathrm{a}} \pm \mathrm{SEM}$ (ng/band) & $\%$ RSD & Calculated amount $^{\mathrm{a}} \pm \mathrm{SEM}$ (ng/band) & $\% \mathrm{RSD}$ \\
\hline \multicolumn{5}{|l|}{ OLM } \\
\hline 80 & $79.12 \pm 0.20$ & 0.44 & $82.41 \pm 0.47$ & 0.98 \\
\hline 320 & $323.10 \pm 0.24$ & 0.13 & $325.60 \pm 0.90$ & 0.48 \\
\hline 480 & $485.62 \pm 0.94$ & 0.34 & $483.13 \pm 1.36$ & 0.38 \\
\hline \multicolumn{5}{|l|}{ HTZ } \\
\hline 25 & $26.15 \pm 0.15$ & 0.99 & $25.93 \pm 0.26$ & 1.73 \\
\hline 100 & $102.36 \pm 0.29$ & 0.50 & $101.95 \pm 0.64$ & 1.08 \\
\hline 150 & $156.91 \pm 0.71$ & 0.78 & $153.12 \pm 1.53$ & 1.08 \\
\hline
\end{tabular}

a Mean of three replicates, RSD: relative standard deviation, SEM: standard error mean.

TABle 3: Accuracy study by standard addition method.

\begin{tabular}{|c|c|c|c|c|c|}
\hline Drug & $\begin{array}{l}\text { Initial amount } \\
\text { (ng/band) }\end{array}$ & $\begin{array}{l}\text { Fortified } \\
\text { amount } \\
\text { (ng/band) }\end{array}$ & $\begin{array}{c}\text { Amount } \\
\text { recovered }^{\mathrm{a}} \pm \text { SEM } \\
(\mathrm{ng} / \mathrm{band})\end{array}$ & Mean recovery (\%) & $\%$ RSD \\
\hline \multirow{3}{*}{ Olmesartan medoxomil } & 80 & 25 & $105.92 \pm 0.24$ & 100.88 & 0.40 \\
\hline & 160 & 50 & $212.56 \pm 0.50$ & 101.22 & 0.50 \\
\hline & 240 & 75 & $313.71 \pm 1.22$ & 99.60 & 0.37 \\
\hline \multirow{3}{*}{ Hydrochlorothiazide } & 25 & 25 & $49.15 \pm 0.14$ & 98.30 & 0.51 \\
\hline & 50 & 50 & $99.32 \pm 0.31$ & 99.32 & 0.54 \\
\hline & 75 & 75 & $148.53 \pm 0.55$ & 99.02 & 0.64 \\
\hline
\end{tabular}

a $\mathrm{a}$ Mean of three replicates, RSD: relative standard deviation, SEM: standard error mean.

TABLE 4: Results from robustness study.

\begin{tabular}{|c|c|c|c|c|c|c|}
\hline \multirow{2}{*}{ Condition } & \multicolumn{2}{|c|}{ Retention factor $\left(R_{f}\right)$} & \multicolumn{2}{|c|}{ Assay $^{\mathrm{a}}(\%)$} & \multicolumn{2}{|c|}{$\% \mathrm{RSD}$} \\
\hline & OLM & HTZ & OLM & HTZ & OLM & HTZ \\
\hline \multicolumn{7}{|c|}{ Mobile phase composition (v/v/v/v) } \\
\hline \multicolumn{7}{|c|}{ Toluene: methanol : ethyl acetate : acetone } \\
\hline$(2.4: 1: 1: 1.5)$ & 0.31 & 0.54 & 100.70 & 101.20 & 0.41 & 0.69 \\
\hline$(2.5: 1: 1: 2.5)$ & 0.32 & 0.53 & 99.30 & 100.76 & 1.21 & 1.08 \\
\hline$(2.5: 0.9: 0.9: 1.5)$ & 0.31 & 0.54 & 98.72 & 97.91 & 0.93 & 0.86 \\
\hline \multicolumn{7}{|c|}{ Development distance $(\mathrm{cm})$} \\
\hline 6 & 0.30 & 0.54 & 98.76 & 101.21 & 0.71 & 0.19 \\
\hline 7 & 0.31 & 0.52 & 97.86 & 99.30 & 0.27 & 0.87 \\
\hline \multicolumn{7}{|c|}{ Time of spotting to chromatogram (min) } \\
\hline 9 & 0.30 & 0.52 & 98.61 & 99.32 & 1.32 & 1.47 \\
\hline 10 & 0.28 & 0.52 & 100.86 & 101.20 & 1.62 & 0.72 \\
\hline \multicolumn{7}{|c|}{ Detection wavelength (nm) } \\
\hline 275 & 0.29 & 0.53 & 98.71 & 99.41 & 1.01 & 0.43 \\
\hline 280 & 0.29 & 0.54 & 98.76 & 99.37 & 0.37 & 0.86 \\
\hline
\end{tabular}

Mean of three determinations, RSD: relative standard deviation.

TABLE 5: Results from degradation study.

\begin{tabular}{lcr}
\hline Degradation condition & $\%$ Degradation & Number of degradation products $\left(R_{f}\right)$ \\
\hline Acid & $5 \%, 3 \%, 8 \%$ & $0.015,0.43$ \\
Alkali & $12 \%, 18 \%, 5 \%$ & $0.10,0.45,0.79$ \\
Oxidative & $22 \%, 5 \%, 1 \%$ & 0.20 \\
Heat & - & - \\
Photolytic (UV) & - & - \\
\hline
\end{tabular}




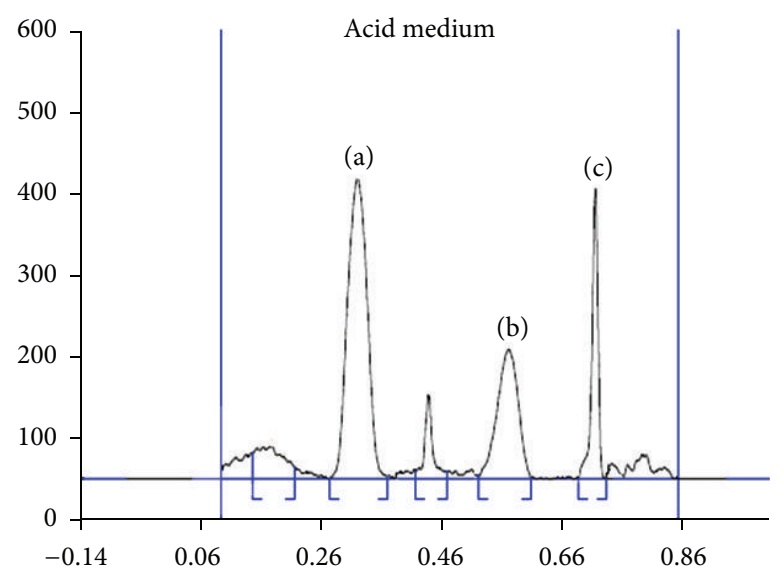

(a)

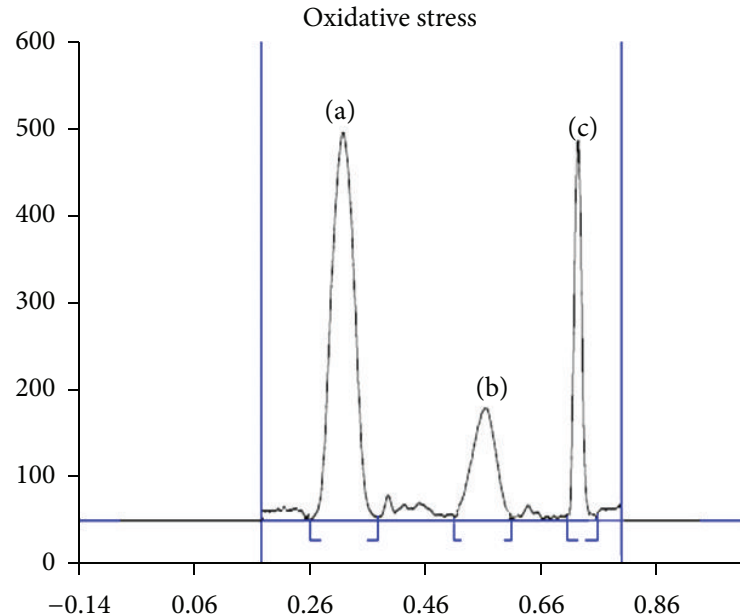

(c)

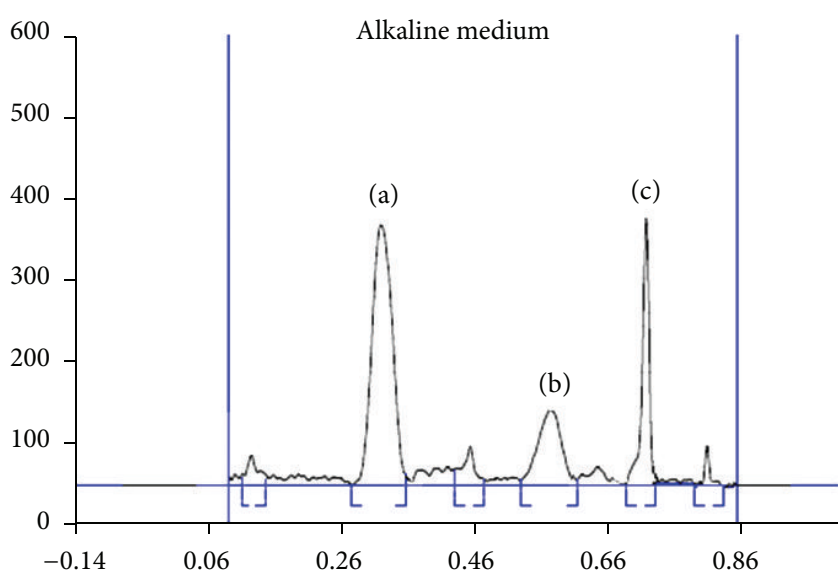

(b)

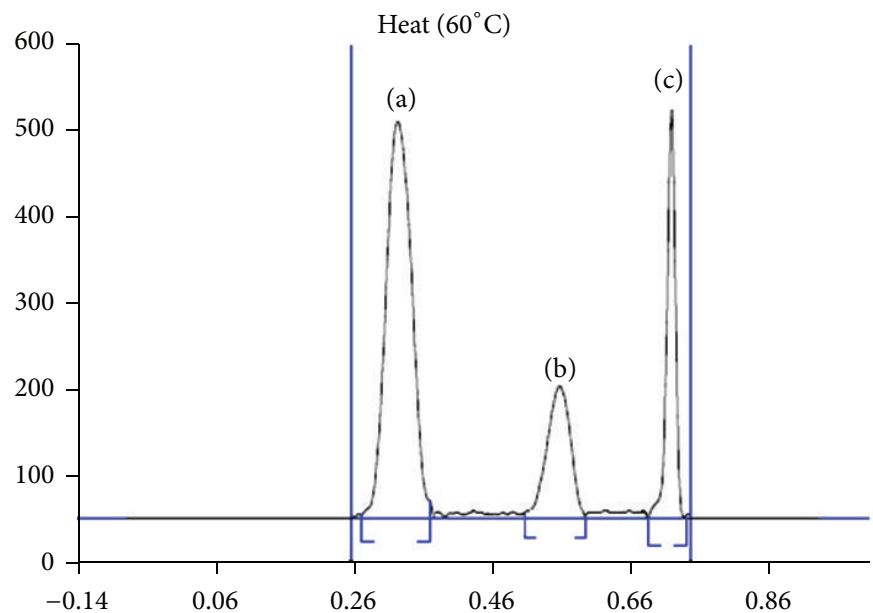

(d)

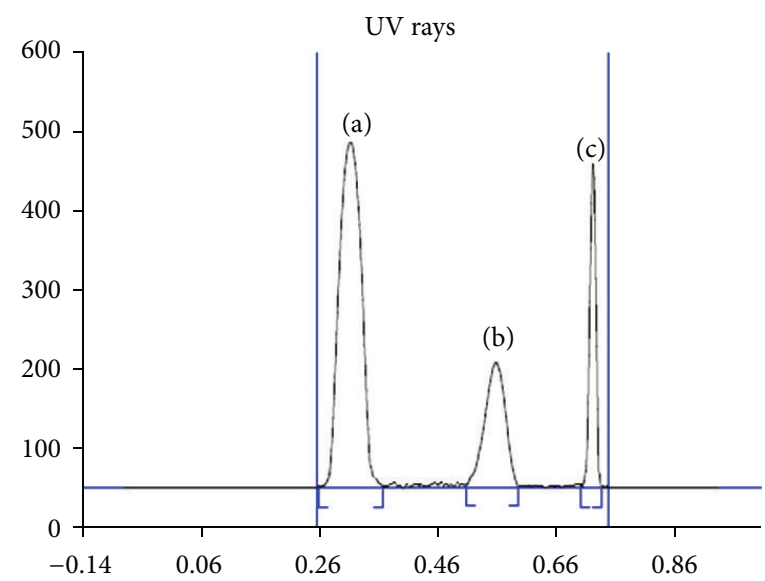

(e)

FIGURE 5: Densitogram obtained after stress testing under different conditions.

through $0.45 \mu \mathrm{m}$ nylon filters (Millipore, Milford, USA). From the resulting sample solution, $2 \mathrm{~mL}$ was transferred to $50 \mathrm{~mL}$ volumetric flask. To this $0.5 \mathrm{~mL}$ of standard stock solution $(1.0 \mathrm{mg} / \mathrm{mL})$ of IS was added and diluted to $50 \mathrm{~mL}$ with methanol to furnish a solution containing $16 \mu \mathrm{g} / \mathrm{mL}$
OLM, $5 \mu \mathrm{g} / \mathrm{mL} \mathrm{HTZ}$, and $10 \mu \mathrm{g} / \mathrm{mL}$ IS, respectively. From the final solution $10 \mu \mathrm{L}$ was spotted as bands and analyzed. Quantification was done using relative retention factor (RRF) for OLM and HTZ. The procedure was repeated five times for analysis of homogenous samples. 
TABLE 6: Results from HPTLC quantification of olmesartan medoxomil and hydrochlorothiazide in tablets.

\begin{tabular}{lcccccrrr}
\hline \multirow{2}{*}{ Sample } & \multicolumn{2}{c}{ Label claim $(\mathrm{mg})$} & \multicolumn{2}{c}{ Amount present ${ }^{\mathrm{a}}(\mathrm{mg})$} & \multicolumn{2}{c}{ SD } & \multicolumn{2}{c}{ \% RSD } \\
& OLM & HTZ & OLM & HTZ & OLM & HTZ & OLM & HTZ \\
\hline Olmesar-H & 40 & 12.5 & 41.05 & 12.42 & 0.17 & 0.21 & 0.41 & 1.69 \\
Olmy-H & 40 & 12.5 & 41.38 & 12.35 & 0.41 & 0.14 & 0.99 & 1.13 \\
\hline
\end{tabular}

Mean of five determinations, SD: standard deviation, RSD: relative standard deviation.

TABLE 7: Comparison of the proposed method with the reported HPLC method.

\begin{tabular}{lcccc}
\hline Parameter & OLM & HPLC & & HPTLC \\
& $4-24 \mu \mathrm{g} / \mathrm{mL}$ & HTZ & $80-480 \mathrm{ng} / \mathrm{band}$ & $25-150 \mathrm{ng} / \mathrm{band}$ \\
Linearity & $0.44 \mu \mathrm{g} / \mathrm{mL}$ & $0.21 \mu \mathrm{g} / \mathrm{mL}$ & $18.12 \mathrm{ng} / \mathrm{band}$ & $6.31 \mathrm{ng} / \mathrm{band}$ \\
LOD & $1.32 \mu \mathrm{g} / \mathrm{mL}$ & $0.63 \mu \mathrm{g} / \mathrm{mL}$ & $56.35 \mathrm{ng} / \mathrm{band}$ & $18.56 \mathrm{ng} / \mathrm{band}$ \\
LOQ & 100.24 & 100.10 & 103.03 & 99.08 \\
$\begin{array}{l}\text { Tablet analysis } \\
\text { (\% recovery) }\end{array}$ & & & \\
\hline
\end{tabular}

\section{Results and Discussion}

\subsection{Chromatographic Method Development and Optimization.} Preliminary experiments were carried out to optimise the parameters affecting simultaneous estimation of both drugs using HPTLC and detection at $258 \mathrm{~nm}$. The solvent type, solvent ratio, and detection wavelength were varied to determine the chromatographic conditions giving best separation. Different solvent types like methanol : ethyl acetate : acetic acid $(4: 2.5: 0.5, \mathrm{v} / \mathrm{v} / \mathrm{v})$, toluene : methanol: ethyl acetate : acetone $(2.5: 1: 0.5: 2, \mathrm{v} / \mathrm{v} / \mathrm{v} / \mathrm{v})$, and toluene $:$ ethyl acetate $:$ acetic acid $(7: 2: 0.5, \mathrm{v} / \mathrm{v} / \mathrm{v})$ were investigated for complete chromatographic resolution of two drugs. Mobile phase consisting of toluene: methanol: ethyl acetate:acetone $(2.5: 1: 0.5: 2$, $\mathrm{v} / \mathrm{v} / \mathrm{v} / \mathrm{v}$ ) was found to give the best sensitivity, efficiency, and peak shape. It gave symmetric, well-resolved spots with $R_{f}$ values of OLM $0.29 \pm 0.02$, HTZ $0.52 \pm 0.01$, and IS $0.71 \pm 0.01$ as shown in Figure 2. The UV spectra of all three analytes were determined independently and in combination. It was observed from overlain spectra (Figure 3 ) that at wavelength $258 \mathrm{~nm}$, all three drugs could be detected simultaneously with no mobile phase interference, good separation, sensitivity, and consistent baseline. All experiments were performed at $28^{\circ} \mathrm{C}$ temperature.

3.2. Method Validation. The method was validated for parameters such as linearity, specificity, LOD, LOQ, precision, accuracy, and robustness.

Densitogram obtained shows no interference between peaks or from other constituents originating from the excipients of tablets. It can also be assumed from peak purity spectra (Figure 4) that the method is specific for these analytes, which enables reliable results to be obtained. The peak purity of more than 0.99 indicates no interference from any impurities in the separation and determination of OLM and HTZ peaks.

The calibration plots were linear in the concentration range $80-480 \mathrm{ng} / \mathrm{spot}(n=3, r=0.9996)$ for OLM and 25$150 \mathrm{ng} / \operatorname{spot}(n=3, r=0.9994)$ for HTZ, respectively. The low values of standard deviation showed that the standard error of slope and the intercept of ordinate showed that the calibration plot did not deviate from linearity. Table 1 shows the linearity parameters of calibration curve.

The intra- and interday precision values were calculated for three concentrations of OLM and HTZ (Table 2). The RSD values were $0.13-0.99$ and $0.38-1.73$ for intra- and interday, respectively. The low $\mathrm{RSD}$ values $(<2 \%)$ indicate sensitivity and repeatability of the proposed method. Reproducibility checked by different analyst shows no significant difference $(\mathrm{RSD} \leq 1.5 \%)$ in the intra- and interday precision.

The recovery study performed at three different concentrations in triplicate shows good recoveries, 99.60-101.22\% for OLM and 98.30-99.32\% for HTZ, respectively. The \% RSD and $\%$ relative error in all cases were within the acceptable limit $(<2 \%)$. The results of recovery study are reported in Table 3.

Results of robustness study are depicted in Table 4 . The retention factor $\left(R_{f}\right)$ and assay (\%) were not significantly affected. RSD (\%) values in all robustness parameters were examined and found to be within the limit of $<2 \%$. The result showed that proposed method is robust and was acceptable for proving data of acceptable quality.

The results of specificity studies showed that OLM and HTZ are stable when exposed to different stress conditions. No significant deviation of $R_{f}$ values or variations of assay values were observed. Densitograms obtained from samples stressed under different conditions are given in Figure 5. Table 5 shows percentage degradation of OLM and HTZ peaks.

The validated HPTLC method was applied for simultaneous determination of OLM and HTZ in commercial tablets (Olmesar-H and Olmy-H). For both brands, $10 \mu \mathrm{L}$ of final sample solution containing $160 \mathrm{ng} / \mathrm{band}$ OLM, $50 \mathrm{ng} / \mathrm{band}$ HTZ, and $100 \mathrm{ng} / \mathrm{band}$ IS was spotted. The chromatogram obtained is identical to that of drug standard solution, without any interference from excipients. The results as depicted in Table 6 indicate that each drug in tablet corresponds to requirements of label claim. The low RSD values $(<2 \%)$ 
confirmed the suitability of method for routine analysis of OLM and HTZ in pharmaceutical dosage forms. Also the proposed method was compared with the reported HPLC method (Table 7).

\section{Conclusion}

The developed HPTLC method combined with densitometry was found suitable for determination of OLM and HTZ in bulk and tablet dosage form without any interference from excipients. Statistical analysis proves that the developed method is repeatable, reproducible, and selective for the analysis of both drugs. Its advantages are low cost of reagents (only $10 \mu \mathrm{L}$ of solution is applied on plate), speed (the entire process took no more than 20 minutes), sensitivity, accuracy and precision. The method has lower LOD and LOQ values and high recovery.

\section{References}

[1] H. Koike, T. Konse, and T. Sada, "Olmesartan medoxomil, a novel potent angiotensin II blocker," Annual Report of Sankyo Research Laboratories, vol. 55, pp. 1-91, 2003.

[2] D. E. Mire, T. N. Silfani, and M. K. Pugsley, "A review of the structural and functional features of olmesartan medoxomil, an angiotensin receptor blocker," Journal of Cardiovascular Pharmacology, vol. 46, no. 5, pp. 585-593, 2005.

[3] D. A. Koechel, J. H. Block, and J. M. Beak, Textbook of Organic Medicinal and Pharmaceutical Chemistry, Lippincott Williams and Wilkins, 2004.

[4] M. Celebier and S. Altinoz, "Determination of olmesartan medoxomil in tablets by UV-Vis spectrophotometry," Pharmazie, vol. 62, no. 6, pp. 419-422, 2007.

[5] S. Ceglar and A. Onal, "Two simple and rapid spectrophotometric methods for the determination of a new antihypertensive drug olmesartan in tablets," Journal of Analytical Chemistry, vol. 65, no. 3, pp. 239-243, 2010.

[6] R. Sharma and S. Pancholi, "RP-HPLC-DAD method for determination of olmesartan medoxomil in bulk and tablets exposed to forced conditions," Acta Pharmaceutica, vol. 60, no. 1, pp. 13-24, 2010.

[7] L. Bajerski, R. C. Rossi, C. L. Dias, A. M. Bergold, and P. E. Fröehlich, "Stability-indicating LC determination of a new antihypertensive, olmesartan medoxomil in tablets," Chromatographia, vol. 68, no. 11-12, pp. 991-996, 2008.

[8] M. Çelebier and S. Altinöz, "Development of a CZE method for the determination of olmesartan medoxomil in tablets," Chromatographia, vol. 66, no. 11-12, pp. 929-933, 2007.

[9] D. Farthing, I. Fakhry, E. B. D. Ripley, and D. Sica, "Simple method for determination of hydrochlorothiazide in human urine by high performance liquid chromatography utilizing narrowbore chromatography," Journal of Pharmaceutical and Biomedical Analysis, vol. 17, no. 8, pp. 1455-1459, 1998.

[10] V. V. Vaidya, S. M. N. Roy, S. M. Yetal, S. S. Joshi, and S. A. Parekh, "LC-MS-MS determination of olmesartan in human plasma," Chromatographia, vol. 67, no. 1-2, pp. 147-150, 2008.

[11] D. Liu, P. Hu, N. Matsushima, X. Li, L. Li, and J. Jiang, "Quantitative determination of olmesartan in human plasma and urine by liquid chromatography coupled to tandem mass spectrometry," Journal of Chromatography B, vol. 856, no. 1-2, pp. 190-197, 2007.
[12] J. Ouyang, W. R. G. Baeyens, J. Delanghe, G. Van Der Weken, and A. C. Calokerinos, "Cerium (IV)-based chemiluminescence analysis of hydrochlorothiazide," Talanta, vol. 46, no. 5, pp. 961-968, 1998.

[13] D. Zendelovska, T. Stafilov, and P. Miloševski, "Development of solid-phase extraction method and its application for determination of hydrochlorothiazide in human plasma using HPLC," Biomedical Chromatography, vol. 18, no. 2, pp. 71-76, 2004.

[14] O. A. Razak, "Electrochemical study of hydrochlorothiazide and its determination in urine and tablets," Journal of Pharmaceutical and Biomedical Analysis, vol. 34, no. 2, pp. 433-440, 2004.

[15] A. R. Rote and P. D. Bari, "Spectrophotometric estimation of olmesartan medoxomil and hydrochlorothiazide in tablet," Indian Journal of Pharmaceutical Sciences, vol. 72, no. 1, pp. 111113, 2010.

[16] K. P. Bhusari, P. B. Khedekar, S. Dhole, and V. S. Banode, "Derivative and Q-analysis spectrophotometric methods for estimation of hydrochlorothiazide and olmesartan medoxomil in tablets," Indian Journal of Pharmaceutical Sciences, vol. 71, no. 5, pp. 505-508, 2009.

[17] A. R. Rote and P. D. Bari, "Ratio spectra derivative and zero-crossing difference spectrophotometric determination of olmesartan medoxomil and hydrochlorothiazide in combined pharmaceutical dosage form," AAPS PharmSciTech, vol. 10, no. 4, pp. 1200-1205, 2009.

[18] B. Kumari, M. D. Burande, and P. K. Choudhari, "Spectrophotometric method for simultaneous estimation of olmesartan medoxomil and hydrochlorothiazide in tablets," Research Journal of Pharmaceutical, Biological and Chemical Sciences, vol. 4, pp. 104-109, 2013.

[19] P. D. Bari and A. R. Rote, "RP-LC and HPTLC methods for the determination of olmesartan medoxomil and hydrochlorothiazide in combined tablet dosage forms," Chromatographia, vol. 69, no. 11-12, pp. 1469-1472, 2009.

[20] S. Kadukar, S. Gandhi, P. Ranjane, and S. Ranher, "HPTLC analysis of olmesartan medoxomil and hydrochlorothiazide in combination tablet dosage forms," Journal of Planar Chromatography, vol. 22, no. 6, pp. 425-428, 2009.

[21] "ICH stability testing of new drug substances and products Q1A (R2)," in Proceedings of the International Conference on Harmonization, 2003.

[22] "ICH validation of analytical procedures: text and Methodology Q2 (R1)," in Proceeding of the International Conference on Harmonization, 2005. 

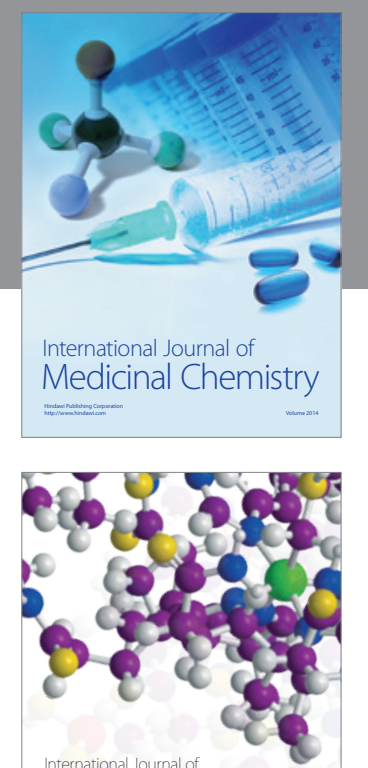

\section{Carbohydrate} Chemistry

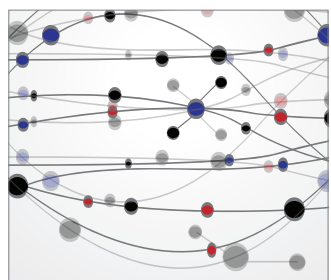

The Scientific World Journal
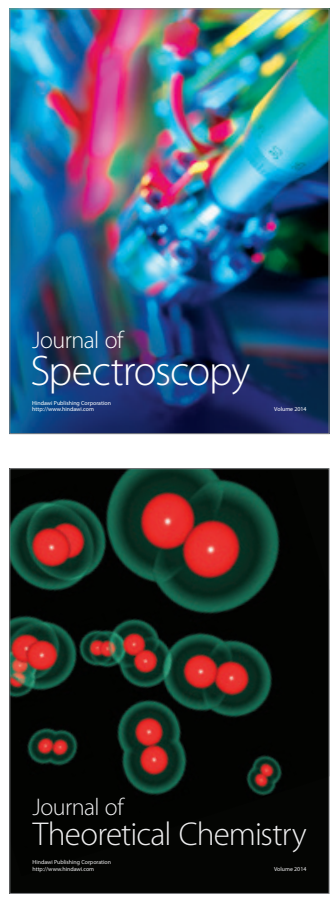
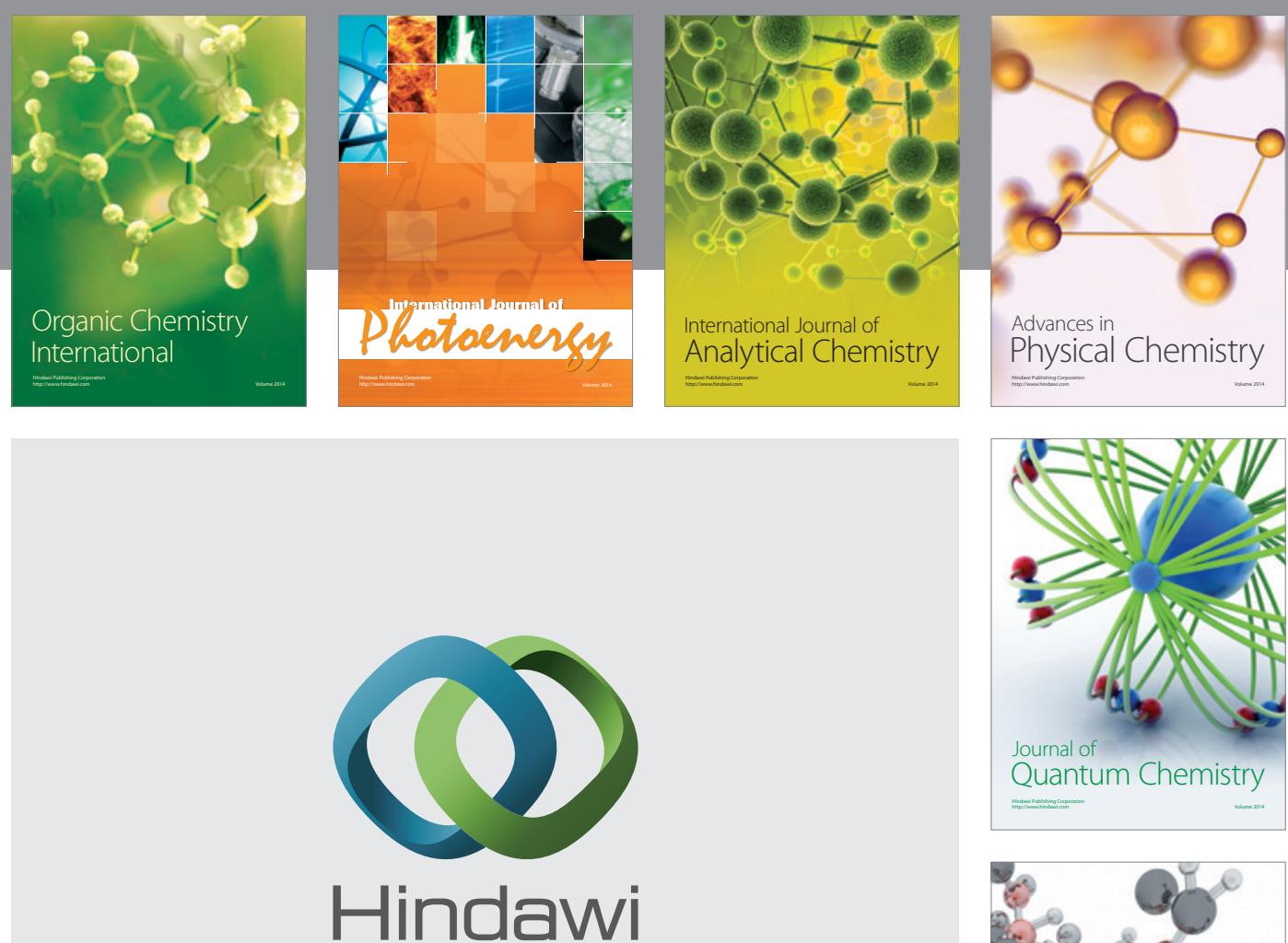

Submit your manuscripts at

http://www.hindawi.com

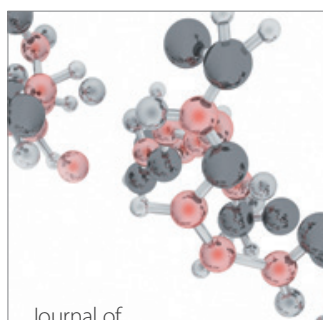

Analytical Methods

in Chemistry

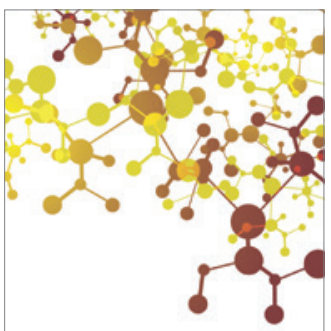

Journal of

Applied Chemistry

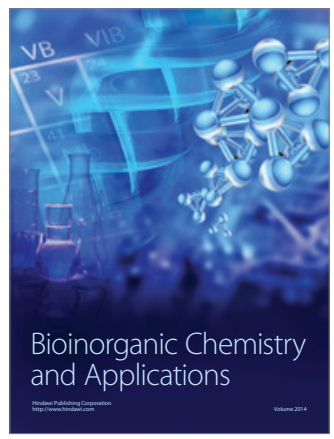

Inorganic Chemistry
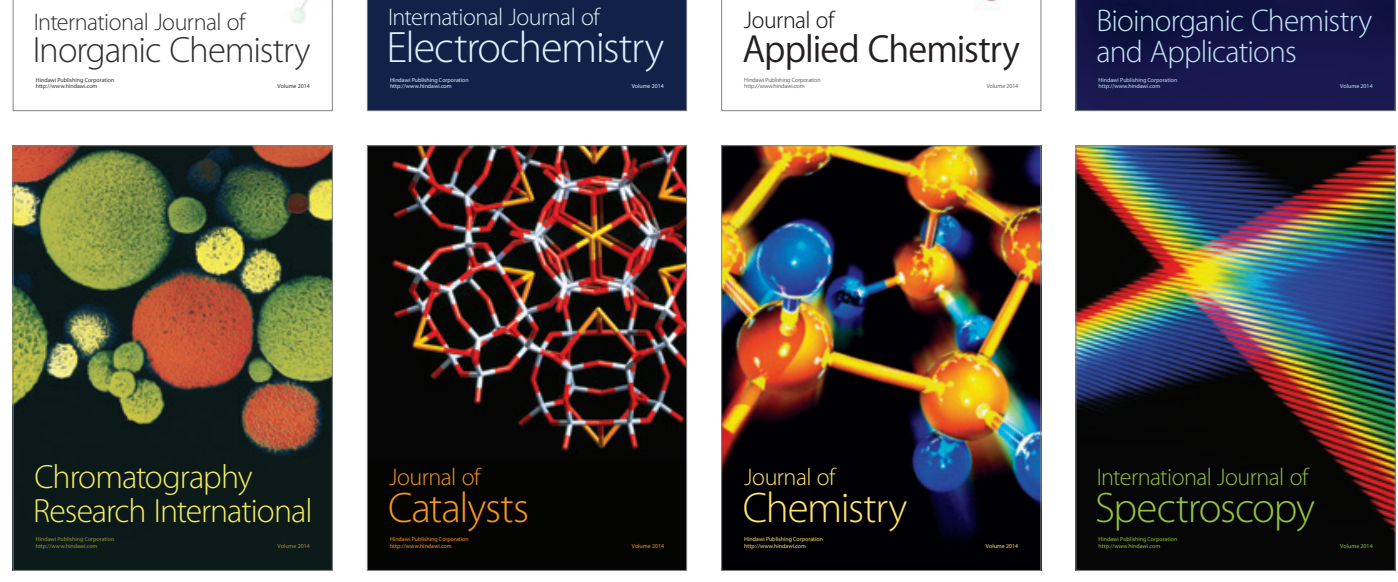